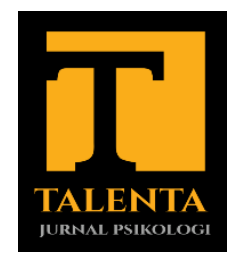

\author{
Volume 6 No 2 Maret 2021 \\ p-ISSN: 2460-8750 e-ISSN: 2615-1731 \\ https://doi.org/10.26858/talenta.v6i2.19167
}

\title{
Appreciative Inquiry untuk Meningkatkan Sense of Community dan Partisipasi Pada Anggota Komunitas Ikatan Pemuda Pemudi Kampung Tengah di Sumbermanjingkulon
}

\author{
Uslarika Hida Rahma $^{1}$, Cholichul Hadi ${ }^{1}$, Ilham Nur Alfian ${ }^{1}$ \\ Fakultas Psikologi, Universitas Airlangga. Indonesia \\ Email: uslarika.hida.rahma-2018@psikologi.unair.ac.id, \\ cholichul.hadi@psikologi.unair.ac.id, \\ ilham.nuralfian@psikologi.unair.ac.id
}

\begin{abstract}
Sense of Community is necessary for sustainability of a community and the involvement of members. This study aims to increase the Sense of Community and social participation of the community members using the Appreciative Inquiry approach in order making positive changes for the community. IPPKT community members at the state low involvement for the community. Intervention is needed in order the members will more participate and actively involve for IPPKT community and making positive changes. The intervention conclude 5 steps of Appreciative Inquiry including define, discover, dream, design, and destiny. The results of intervention are members succeed planning concrete steps with a feeling of pride and motivation to make changes to achieve the dream state whilst focuses on the search for strength in order making positive changes and increasing the involvement of members.Based on the results of statistical analysis, it shows that the intervention of Appreciative Inquiry is effective to increase the sense of community and social participation with a value of $p=0.000<0.05$ and a $t$ value of $4.792>1.701$, which means that there are significant differences before and after the intervention.
\end{abstract}

Keywords: Appreciative Inquiry, Sense of Community, Social Participation

\begin{abstract}
ABSTRAK
Sense of Community dalam suatu komunitas sangatlah penting untuk menjaga keberlanjutan organisasi serta semakin mendorong proaktif anggota. Penelitian ini bertujuan meningkatkan Sense of Community dan partisipasi sosial anggota komunitas dengan pendekatan Appreciative Inquiry sehingga dapat melakukan perubahan organisasi secara positif. Komunitas IPPKT saat ini sedang mengalami penurunan keterlibatan anggota. Sehingga diperlukan intervensi untuk meningkatkan keterlibatan anggota komunitas menggunakan Appreciative Inquiry yang terdiri dari 5 aspek antara lain, define, discover, dream, design, destiny. Metode penelitian tindakan ini yang dilakukan berhasil membuat anggota komunitas IPPKT diberbagai level berpartisipasi
\end{abstract}


aktif mengidentifikasi hal-hal yang dibutuhkan dalam perubahan dan merencanakan langkah nyata dengan perasaan bangga dan termotivasi untuk melakukan perubahan dalam rangka mencapai keadaan yang diimpikan. Penelitian ini menunjukkan bahwa Appreciative Inquiry yang berfokus pada pencarian kekuatan berupa apa yang berjalan baik dalam menciptakan masa depan yang lebih efektif digunakan sebagai metode untuk melakukan perubahan dan pengembangan organisasi.Berdasarkan hasil analisis statistik menunjukkan bahwa penggunaan Appreciative Inquiry efektif dalam meningkatkan sense of community dan partisipasi sosial dengan nilai $p=0,000<0,05$ dan nilai $t$ sebesar 4,792 > 1,701 yang artinya terdapat perbedaan yang signifikan sebelum dan setelah dilakukan intervensi.

Kata Kunci: Appreciative Inquiry, Sense of Community, Partisipasi Sosial

\section{PENDAHULUAN}

Perkembangan desa merupakan bagian penting dari proses pengembangan dan pembangunan desa demi kemajuan serta kesejahteraan masyarakat. Konsep pengembangan desa tidak hanya peran pemerintah setempat namun keterlibatan aktif dari para pemuda-pemudi sangat dibutuhkan. Peran pemuda sangat dibutuhkan dalam proses keberlanjutan pembangunan desa dengan pemikiranpemikiran sumbangsihnya, karena aktivitas pemuda saat ini sangat dekat dengan kecepatan informasi dan perkembangan teknologi. Keberadaan pemuda dalam suatu daerah sesungguhnya memiliki peran yang besar, sehingga dapat dikatakan bahwa maju mundurnya suatu negara sedikit banyak ditentukan oleh pemikiran dan kontribusi aktif dari pemuda. Begitu juga dalam pembaruan dan pembangunan daerah, pemuda mempunyai fungsi dan peran yang sangat strategis sehingga perlu dikembangkan potensi dan perannya melalui penyadaran, pemberdayaan, dan pengembangan sebagai bagian dari pembangunan nasional.

Beberapa daerah mulai memiliki suatu kelembagaan sosial atau komunitas yang berfokus pada program pengembangan desa. Komunitas-komunitas yang terbentuk tersebut wujud dari peran para pemuda maupun pemudi yang ingin berpartisipasi dalam mewujudkan perubahan dalam lingkungannya. Keberadaan komunitas selalu diharapkan sebagai agen perubahan yang diwujudkan dalam bentuk kemajuan dibidang pengembangan desa. Komunitas yang terbentuk merupakan kelompok sosial yang dinyatakan sebagai masyarakat setempat yang bertempat tinggal dalam suatu wilayah tertentu, dan memiliki ketertarikan yang sama (Loren O, 1984). Komunitas Ikatan Pemuda Pemudi Kampung Tengah (IPPKT) sebagai organisasi sosial yang berada di Sumbermanjingkulon. Komunitas tersebut merupakan sekelompok pemuda maupun pemudi yang mendedikasikan dirinya untuk berproses dalam membangun perubahan di desa Sumbermanjingkulon Kab. Malang. Berdirinya komunitas ini melihat dari tahun 2014 hingga 2016 tidak ada bentuk program pengembangan desa dan dari tahun ketahun semakin menurun menurut Prastata Kepala Komunitas IPPKT. 
Komunitas IPPKT terbentuk pada tahun 2016 yang tentunya memiliki banyak tantangan. Berdasarkan Adizes (2004), sebuah organisasi yang telah diwujudkan dan telah menjalankan ide-ide serta kreativitasnya secara otomatis telah memasuki tahap Go-Go dan menuju tahap adolenscence. Organisasi yang berada pada tahap ini membutuhkan perhatian yang sangat tinggi terutama mulai menentukan kebutuhan organisasi yang menjadi sebuah aturan tertulis dan mulai memilah kegiatan-kegiatan yang penting. Hal ini sangat diperlukan dalam organisasi untuk mampu menuju tahap adolensence, dan akan banyak benturan yang terjadi pada organisasi. Tujuan terbentuknya IPPKT yaitu untuk menjadi komunitas yang bisa memberikan perubahan kecil untuk kesejahteraan desa Sumbermanjingkulon dengan mengajak para pemuda-pemudi menjadikan lebih produktif dan kreatif dengan membuat program-program pengembangan desa.

Berdasarkan hasil wawancara dengan Prastata (Kepala Komunitas IPPKT) pada tanggal 4 Januari 2020, pada keberjalanannya program tersebut mempunyai beberapa tantangan. Beberapa anggota komunitas mulai melalaikan tanggungjawabnya untuk menjalankan program-program tahunan. Anggota mulai kurang proaktif dalam menjalankan kewajibannya di komunitas dan memasuki tahun 2019, beberapa program tahunan tidak terlaksana.

Sebagai organisasi yang sedang berada dalam fase menuju tahap Adolensence, fokus utama komunitas adalah dengan menentukan kebutuhan utama komunitas dengan melihat pada masa Go-Go sudah banyak implementasi ide-ide dan kreativitasnya. Dengan adanya Program-program yang sudah dirancang hendaknya mempunyai daya keberlanjutan serta dapat diimplementasikan dalam setiap tahunnya, dan dibutuhkan aturan tertulis yang menjadi pakem komunitas. Hasil diskusi bersama Kepala desa setempat, beliau menjelaskan bahwa pada saat ini kondisi komunitas tersebut sudah berada diambang batas, untuk mampu mempertahankan eksistensi tersebut sangat dibutuhkan wujud program kerja yang lebih kreatif, inovatif dan menantang sehingga akan menciptakan keadaan yang lebih produktif serta seluruh anggota bisa lebih proaktif dengan program-program yang kreatif dan unik. Oleh karena itu, untuk mampu menunjang pada fase ini dibutuhkan anggota yang terlibat aktif, sehingga akan mampu mencapai fase Adolensence dan tujuan komunitas.

Keterlibatan aktif dari keseluruhan anggota sangatlah penting untuk mencapai tujuan jangka panjang dan jangka pendek yang telah terprogram. Keterlibatan aktif pengurus dan anggota IPPKT merupakan hal utama sebagai penggerak dalam program yang telah dirancang.Ada satu hal penting yang diperlukan oleh para anggota maupun pengurus komunitas IPPKT untuk dapat melibatkan dirinya secara aktif dalam menjalankan tujuan organisasi, yaitu tentang rasa kebersamaan atau sense of community. 


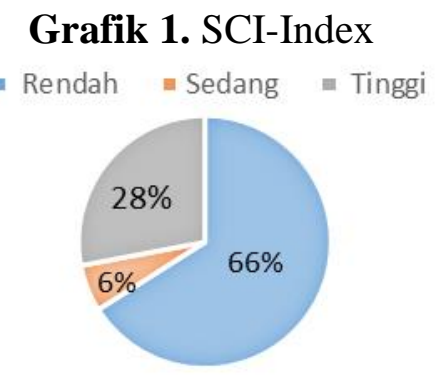

Mengetahui lebih mendalam terkait masalah di komunitas IPPKT yang berhubungan dengan keterlibatan secara aktif, penulis melakukan survey dengan menyebarkan skala sense of community. Berdasarkan hasil preliminary didapatkan hasilbahwa $6 \%$ anggota cenderung sedang, $28 \%$ pada skala tinggi, dan $66 \%$ pada skala rendah.

Hasil tersebut dapat dijelaskan bahwa rendahnya tingkat sense of community berpengaruh pada tingkat keterlibatan aktif dari anggota komunitas IPPKT dalam menjalankan tugas dan tanggungjawab. Keadaan ini berdampak pada program yang dirancang tidak berjalan. Dari hasil tersebut sesuai dengan hasil wawancara dengan kepala komunitas bahwa anggota mulai kurang proaktif dalam menjalankan kewajibannya. Keterhubungan secara personal yang rendah mengakibatkan rencana program komunitas tidak berjalan maksimal.

Rendahnya sense of community yang berpengaruh pada rendahnya keterlibatan aktif para anggota, ada beberapa faktor yang mempengaruhi hal tersebut seperti (a) adanya kepuasan pencapaian dalam komunitas, (b) belum adanya Rencana kerja yang pakem, (c) beberapa anggota masih belum memahami misi dari komunitas dan (d) para anggota berasumsi bahwa komunitas merupakan organisasi bersifat sosial yang kurang menguntungkan.

Apabila permasalahan yang ada dalam komunitas tersebut terus berlanjut dan tidak ada perubahan yang dilakukan, maka dampak atau ancaman yang muncul dari keadaan komunitas IPPKT yaitu rencana kerja tahunan akan terhenti hanya rencana bulanan akan tetap berjalan dan bersifat monoton. Hal tersebut akan menurunkan proaktif masyarakat untuk turut serta dalam kegiatan tersebut. Jika keterlibatan anggota komunitas IPPKT dalam setiap program semakin berkurang maka dalam jangka panjang komunitas yang sudah dibentuk ini akan terbengkalai. Berdasarkan teori Adizes (2004) organisasi yang tidak berjalan optimal lama kelamaan akan menuju tahap Death, organisasi akan mengalami penuaan dini. Oleh karena itu dibutuhkan perubahan dalam organisasi kepada para anggota IPPKT untuk tetap berkomitmen mengemban tanggungjawab dan melaksanakan program-program yang sudah dirancang. 
Sense of community merupakan core values dalam psikologi komunitas, yang mana harus dimiliki untuk mewujudkan anggota yang terlibat aktif dan berpartisipasi untuk membangun komunitas yang lebih produktif. Anggota yang memiliki sense of community yang tinggi akan terlibat aktif dalam suatu komunitas begitupun sebaliknya (Ohmer, L Mary, 2007). Oleh karena itu dapat disimpulkan bahwa sense of community harus dimiliki dari masing-masing anggota agar mampu terlibat aktif dalam keberlanjutan komunitas.

Intervensi berbasis psikologi positif yang akan dilakukan adalah dengan Appreciative Inquiry (AI). Peneliti melihat AI dapat dilakukan untuk meningkatkan sense of community dan partisipasi sosial anggota komunitas IPPKT karena melihat kondisi sekarang berada pada tahap Go-go dan menuju tahap Adolencesemaka sangat dibutuhkan wujud langkah nyata yang baru dengan menentukan pola atau strategi baru untuk menjaga eksistensi komunitas IPPKT.

Appreciative Inquiry (AI) adalah sebuah proses konstruktif untuk mempertanyakan segala sesuatu yang bertujuan mencari tahu apa saja yang membuat organisasi, masyarakat, serta sistem kehidupan manusia menjadi bermakna disaat sedang dalam kondisi terbaiknya yaitu dimana segala sesuatu berjalan efektif, kreatif dan hubungan antar manusia berjalan dengan baik (Cooperrider, 2008). Dengan berprinsip 4-D (Discovery, Dream, Design, Destiny)

\section{METODE}

Penelitian yang akan dilakukan di Ikatan Komunitas Pemuda Pemudi Kampung Tengah menggunakan teknik penelitian tindakan (action research). Penelitian tindakan didefinisikan sebagai sebuah pendekatan kolaboratif dimana peneliti terlibat langsung secara aktif dalam pemecahan masalah. Penelitian tindakan terdiri atas proses yang berkesinambungan dan berulang dari menganalisis permasalahan, perencanaan, melakukan tindakan, melakukan evaluasi, melakukan perencanaan kembali dan seterusnya (Coghlan dan Brannick, 2005). Siklus proses dalam Action Research saling berkesinambungan dan berulang dari proses mengobservasi masalah, merefleksikan serta merencanakan tindakan, melakukan tindakan, mengevaluasi tindakan, memodifikasi, melakukan perencanaan kembali dan seterusnya.

Populasi dalam penelitian ini adalah melibatkan seluruh kepengurusan komunitas IPPKT yang berjumlah 30 anggota. Karakteristik pada penelitian ini terdiri atas seluruh anggota komunitas baik yang aktif maupun jarang terlibat dengan jumlah 23 laki-laki dan 7 perempuan. Rentang usia seluruh subyek yaitu 20-50 tahun yang dikarakteristikan menjadi satu kelompok penelitian. Seluruh subyek ini nantinya yang akan diberikan intervensi guna bisa memberikan perubahan pada organisasi.

Dalam proses penelitian, penulis melakukan langkah-langkah dalam pelaksanaan penelitian, sebagai berikut: 
1) Langkah 1: Menciptakan rasa keterdesakan(sense of urgensi)

Untuk menciptakan rasa keterdesakan penulis menunjukkan kepada Kepala Komunitas IPPKT bahwa diperlukan perubahan untuk meningkatkan rasa kebersamaan (sense of community). Hal ini dengan menunjukkan hasil preliminary dari para anggota komunitas yang mayoritas pada skala rendah, sehingga berefek pada keadaan anggota yang kurang terlibat dalam menjalankan misi komunitas. Proses menumbuhkan sense of urgency tersebut dilakukan dilakukan agar pihak komunitas memahami mengapa harus melakukan perubahan, mengapa perubahan dilakukan saat ini, serta resiko apa saja yang akan dialami ketika perubahan itu tidak dilakukan.

2) Langkah 2: Membentuk sebuah kelompok pengarah

Langkah berikutnya yang dilakukan adalah membuat sebuah kelompok yang dapat mengarahkan proses perubahan dalam komunitas IPPKT. Menurut Kotter dan Cohen (2002) orang-orang yang ada dalam kelompok ini haruslah orang dengan kompetensi yang disesuaikan dengan agenda perubahan, memiliki kapasitas sebagai seorang pemimpin, dianggap kredibel oleh anggota organisasi, dam mampu melakukan tugas tertentu yang dibutuhkan dalam proses perubahan organisasi.

Hal pertama yang dilakukan adalah dengan cara memetakan pihak-pihak yang terkena dampak dari perubahan baik langsung maupun tidak langsung serta pihak-pihak yang memiliki pengaruh dalam keberhasilan sebuah perubahan. Berkaitan dengan perubahan yang akan dilakukan di Komunitas IPPKT, pemetaan tersebut terlihat dalam tabel berikut:

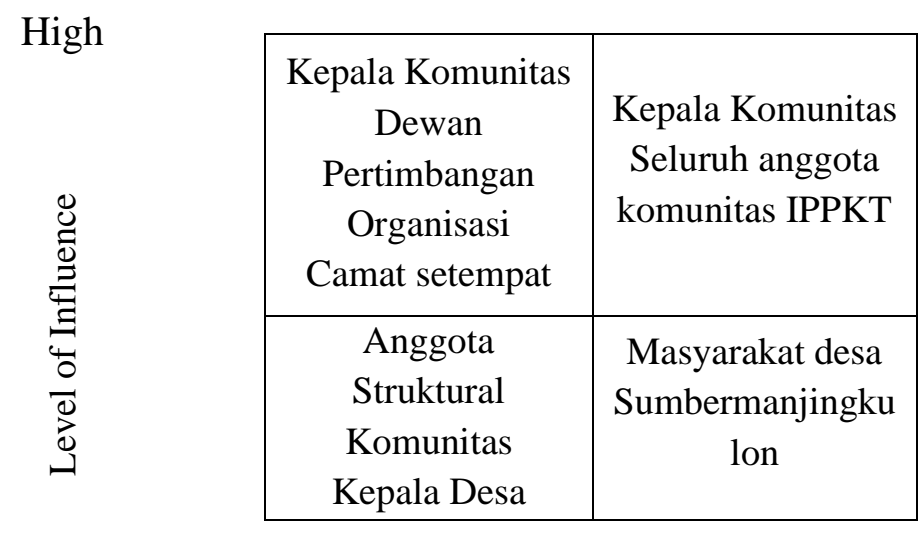

Low

$$
\text { Level of Impact High }
$$

Dari pemetaan tersebut terlihat bahwa yang memiliki pengaruh besar dan terkena dampak yang paling besar adalah Kepala Komunitas IPPKT selaku pimpinan di Komunitas dan seluruh anggota komunitas. oleh karena itu kelompok 
yang akan menjadi katalisator perubahan adalah anggota komunitas dengan sponsor perubahan Kepala Komunitas IPPKT.

3) Langkah 3: Tahapan Intervensi

Sebelum melaksanakan intervensi langkah awal yang dilakukan penulis dengan memberikan pretest SCI-Index 2 kepada para anggota komunitas IPPKT, hal ini untuk mengetahui gambaran tentang keadaan Sense of Community anggota. Setelah pelaksanaan proses pretest, yaitu pemberian intervensi Appreciative inquiry.

Dalam langkah pelaksanaan intervensi yang akan dilakukan peneliti dengan menggunakan pendekatanAppreciative Inquiry (AI) melalui metode 4D. AI memiliki empat tahapan dalam melakukan perubahan yaitu: Discovery, Dream, Design, Destiny. Setiap proses AI dapat berbeda-beda disetiap organisasi, didesain secara khusus dan unik sesuai kebutuhan dan tantangan yang dimiliki organisasi. Oleh karena itu, AI dapat disesuaikan, diubah dan berkembang dengan cara yang sesuai dengan organisasi dan agenda perubahan. Dalam penerapannya fasilitator maupun antar anggota komunitas diharapkan untuk banyak menggali kekuatankekuatan positif dan harapan positif antara satu anggota dengan anggota lainnya dengan dasar saling menghargai perbedaan dan tidak saling memojokkan anggota lainnya. Dalam penelitian ini penulis membagi desain intervensi menjadi 2 intervensi yaitu Intervensi I dan Intervensi II. Langkah-langkah yang dilakukan adalah sebagai berikut:

1. Intervensi I

Pada intervensi I ini penulis melakukan pendekatan dengan menjelaskan konsep dasar terkait keadaan komunitas yang terjadi saat ini sesuai dengan penjabaran Adizes (2004). Hal ini sebagai langkah awal guna memberikan penjabaran lebih jelas sebelum melakukan proses intervensi Appreciative Inquiry. Sehingga anggota komunitas bisa lebih terbuka dan mudah untuk memetakan kondisi organisasi dalam merumuskan proses rangkaian AI.

Kemudian penyampaian materi perihal pentingnya untuk berperan aktif dalam suatu organisasi. Proses penyampaian dengan metode kelas diskusi, penjabaran materi oleh fasilitator kemudian proses tanya jawab. Hal ini sebagai langkah dasar untuk pemahaman terhadap proses intervensi selanjutnya yaitu pelaksanaan Appreciative Inquiry yang merupakan intervensi II.

2. Intervensi II

Setelah intervensi I selesai dilakukan dan para anggota memahami tujuan dari penelitian, penulis mulai melakukan pelaksanaan intervensi menggunakan metode Appreciative Inquiry. Seluruh peserta turut serta dalam kegiatan tersebut untuk menggali dari proses 4-D. 
a. Topik Afirmative

Merupakan langkah awal Appreciative Inquiry untuk memilih sebuah topic yang akan dibahas. Topic yang akan dipilih berfokus pada dimensi partisipasi sosial serta harus bersifat affirmative mengandung antusiasme dan mengarah pada tindakan positif, serta pertanyaan yang diberikan akan mengarahkan apa yang akan didiskusikan dan capaian kedepan.

b. Discovery. Pada tahap ini adalah proses menggali informasi pada anggota dan menghargai apa yang dimiliki oleh individu dari mendengar cerita keberhasilan atau pengalaman yang paling berharga. Bercerita akan pengalaman keberhasilan dimasa lalu dan mencari tahu penyebabnya, siapa saja yang terlibat dan bagaimana mencapainya. Kemudian dari hasil cerita masing-masing anggota dikelompokkan dan dipetakan kekuatan yang ada pada diri individu, setelah itu dirangkum dengan kekuatan anggota lainnya untuk menjadi kekuatan dalam komunitas.

c. Dream, pada tahap ini para peserta diajak untuk bermimpi dan berimajinasi akan masa depan yang diharapkan tentang komunitas, lingkungan, dan diri sendiri dengan mengaitkan pada kekuatan di tahap sebelumnya. Pada tahap ini pula individu diajak untuk menciptakan gambaran akan masa depan yang positif dan proaktif yang memberikan kekuatan untuk mencapai impian.

d. Design, pada proses ini yaitu anggota diajak untuk melakukan identifikasi kekuatan serta potensi yang dimiliki untuk dapat mencapai mimpi besar yang ingin dicapai. Dalam proses perumusan strategi perlu disesuaikan dengan kekuatan dari individu maupun kelompok untuk menghasilkan rencana yang bersifat provokatif untuk mencapai tujuan bersama. Tujuan pada tahap ini memunculkan kekuatan untuk menyampaikan mimpi. Aktivitas yang akan dilakukan adalah menyusun action plan untuk mengimajinasikan hal-hal kecil apa yang dapat dilakukan sehingga berdampak besar terhadap keyakinan dalam mengemban tugas sebagai anggota komunitas dan diharapkan mampu menyusun apa yang akan dilakukan untuk mencapai mimpi besar sebagai anggota komunitas.

e. Destiny, pada tahap terakhir ini lebih berfokus pada penegasan rencana yang telah ditetapkan bersama, selain itu tahap ini juga menekankan kembali peranan dan komitmen dari individu serta komunitas untuk mencapai impian bersama. Tahapan ini diharapkan bagi peserta agar termotivasi dan berkomitmen atas impian-impian selanjutnya.

Appreciative Inquiry memiliki perbedaan dengan pendekatan atau metode lain, yaitu diawali dari pengalaman positif, harapan dan kekuatan masing-masing anggota komunitas dalam membangun suatu organisasi. AI 
tidak berawal dari akar permasalahan yang bersifat mencari pihak yang bertanggung jawab atau berangkat dari pengalaman negatif (kegagalan) individu atau organisasi. Selain itu pendekatan AI akan melibatkan keseluruhan anggota organisasi baik pimpinan tertinggi hingga anggota komunitas untuk berpartisipasi bersama menciptakan masa depan organisasi. Hal tersebut yang mendasari peneliti menggunakan pendekatan AI, dikarenakan konteks dalam komunitas IPPKT ini memiliki budaya kekeluargaan dan gotong royong yang kuat.

4) Langkah Keempat: Penguatan

Setelah intervensi diberikan, pada tahap ini fasilitator memperkuat kembali sejauh mana peserta memahami selama proses intervensi berlangsung. Peserta diajak untuk mengingat kembali apa yang ditangkap oleh peserta dengan mendengarkan apa yang telah diperoleh selama proses, serta rencana berikutnya setelah mengikuti proses pelatihan ini.

5) Langkah kelima : Refleksi dan Evaluasi Intervensi

Pada tahap ini penulis melakukan tinjauan ulang dengan memastikan apakah proses pelatihan ini memiliki dampak atau tidak terhadap seluruh komponen komunitas. Pada proses ini penulis melakukan proses FGD yang dilaksanakan dengan para sesepuh atau Dewan Pertimbangan Organisasi, proses ini dilakukan dengan tujuan merefleksikan kembali sejauh mana manfaat dan proses (jangka pendek) yang dilalui pengurus dalam pengembangan organisasi dan seberapa besar dampak intervensi tersebut memberikan perubahan dan juga untuk mengetahui jangka panjang apa yang sedang dilakukan oleh seluruh komponen komunitas. Selain itu peneliti juga memaparkan data observasi. Hal tersebut sebagai bahan evaluasi proses yang sudah berjalan. Hasil FGD akan dipergunakan sebagai masukan untuk pengembangan komunitas IPPKT. Serta melakukan pengukuran uji T-test dari hasil data pretest-postest untuk melihat ada tidaknya perubahan setelah dilakukan intervensi. Dengan menggunakan alat ukur Sci-Index 2oleh McMillan \&Chavis dan dilakukan uji validasi oleh Paterson, N., Speer, P\& McMillan (2007) dan Hanley (2011) dan sudah dilakukan uji validitas dan reliabilitas oleh peneliti.

\section{HASIL DAN PEMBAHASAN}

\section{Hasil}

Berdasarkan hasil penelitian tersebut dari pelaksanaan intervensi I berfokus pada pengenalan dan pendalaman terkait keadaan yang ada dalam komunitas dengan berpedoman dengan hasil preliminary dan Lifecycle (Adizes, 2004). Pada intervensi II berfokus pada pelaksanaan Appreciative Inquiry. Intervensi Appreciative inquiry yang dilakukan secara sistematis dan terencana berhasil mengajak seluruh anggota komunitas IPPKT untuk berani memimpikan kondisi komunitas sesuai dengan harapan mereka serta dapat merencanakan tindakan 
untuk bisa mencapai mimpi yang sudah direncanakan dalam jangka waktu 6 bulan kedepan.

Pada tahapan Dream dan Discovery, yang fokus 1 tentang pengalaman positif selama berada di Komunitas IPPKT dan fokus 2 tentang memimpikan kemungkinan terbaik untuk meningkatkan keterlibatan aktif para anggota komunitas. Pada tahap 1 peneliti memberikan satu lembar kertas kosong untuk diberikan kepada peserta, dalam kertas itu diminta untuk masing-masing anggota menceritakan pengalaman positifnya berada di komunitas berdasarkan pertanyaan dari penulis. Setelah selesai dipersilahkan untuk beberapa anggota bercerita dan selebihnya ditempel dipapan yang telah disediakan dan nanti akan dikelompokkan dengan satu tema yang hampir sama.

Setelah proses penyampaian cerita oleh beberapa anggota selesai, selanjutnya bersama-sama dengan seluruh anggota menyusun kekuatan-kekuatan yang sudah ditempel pada papan. Hal ini bertujuan untuk menyebarkan kekuatan positif kepada seluruh anggota komunitas. Dari hasil Discovery tersebut bahwa terdapat tiga kekuatan positif yang dimiliki komunitas yaitu (1) komunitas IPPKT merupakan tempat untuk saling bertukar pikiran dengan seluruh anggota komunitas. (2) komunitas IPPKT memiliki karakter yang kompak. (3) Komunitas IPPKT berasas kekeluargaan sehingga kebersamaan dengan anggota sangat melekat.

Selanjutnya penulis mengajak para anggota untuk memasuki sesi Dream. Peneliti menyampaikan untuk lima tahun kedepan apa mimpi seluruh anggota terhadap komunitas. Seluruh anggota diminta menuliskan pada sebuah kertas berbentuk buah apel dan setelah selesai diminta kembali untuk menempelkan pada pohon impian IPPKT.Terdapat lima pokok impian yang seluruh anggota tuliskan, yaitu:

1. Menjadikan komunitas IPPKT yang tetap solid serta bisa menjalankan program yang telah disusun dan berguna bagi masyarakat desa Sumbermanjingkulon.

2. Seluruh anggota terpilih tetap berkomitmen dan akan selalu terlibat aktif untuk menambah program kegiatan sosial sehingga mampu menjadikan komunitas IPPKT terbaik di Malang selatan

3. Komunitas IPPKT mampu berkolaborasi dengan komunitas lain atau organisasi besar, sehingga akan tercipta ide-ide baru dan gagasan baru untuk komunitas IPPKT kedepan

4. Komunitas IPPKT memiliki anggota yang pakem serta mampu berkontribusi dalam menyelesaikan tanggungjawabnya dan yang nantinya akan memberikan arti bagi lingkungan sekitar

5. Komunitas IPPKT memiliki pengaruh terhadap perbaikan ekonomi baik secara sosial dan individu 
Mimpi-mimpi yang sudah dituliskan seluruh anggota dan sudah dikelompokkan, dirangkum tersebut bisa menjadi suatu keterdesakan dalam komunitas untuk melakukan perubahan. Salah satu cara yang dapat dilakukan untuk meningkatkan rasa keterdesakan adalah dengan terus menurus memberikan informasi kepada seluruh anggota mengenai kemungkinan masa depan yang bisa dicapai, keuntungan besar yang akan didapatkan ketika berhasil mencapai masa depan tersebut dan pentingnya organisasi berhasil melakukan perubahan dengan seluruh anggota mampu terlibat aktif kembali untuk mencapai mimpi-mimpinya.

Pada sesi Discovery dan Dream ini sesuai dengan McMillan (2011) bahwa Share Emotional Connection yang positif dengan berbagi pengalamanpengalaman, sejarah anggota yang sama dan waktu bersama-sama akan menciptakan mimpi baru dengan keadaan yang lebih baik kedepannya. Hal ini sesuai dengan prinsip Share Emotional Connection yaitu pertama akan menciptakan suatu ContactHypnosis bahwa semakin positif dalam berinteraksi akan semakin mengikat dan semakin dekat seluruh anggota komunitas. Kedua Quality of interaction yang mana semakin positif pengalaman dan antar anggota maka akan semakin besar ikatannya. Hal ini terlihat selama proses menceritakan pengalaman berharga mereka bersama anggota lainnya dan komunitas. Ketiga Sharedvalent event hypothesis, bahwa semakin penting suatu kejadian yang dibagikan atau diceritakan dengan melibatkan anggota lain maka akan semakin besar ikatan komunitas terbentuk. Pada saat berbagi pengalaman positif dengan anggota lainnya, terlihat masing-masing dari mereka merasa dihargai dan semangat ketika memberikan respon dan tanggapan yang diberikan.

Pada tahap selanjutnya menggali sesi Design dan Destiny.Pada proses ini untuk menentukan langkah-langkah yang akan dilakukan di komunitas IPPKT, faktor apa saja yang dibutuhkan oleh komunitas IPPKT supaya impian bersama yang sudah dibuat dalam pohon impian tersebut bisa tercapai. Dari diskusi dan pendapat yang sudah dikemukakan oleh seluruh anggota, penulis mengajak untuk membuat kesimpulan dan mengelompokannya agar lebih mudah dipahami. Berikut untuk hasil yang diperoleh dalam melakukan perubahan. 
Tabel. 1 Hal-hal yang Dibutuhkan Untuk Perubahan

\begin{tabular}{|c|c|}
\hline Tema & Hal yang dibutuhkan \\
\hline $\begin{array}{l}\text { Struktur } \\
\text { Organisasi }\end{array}$ & 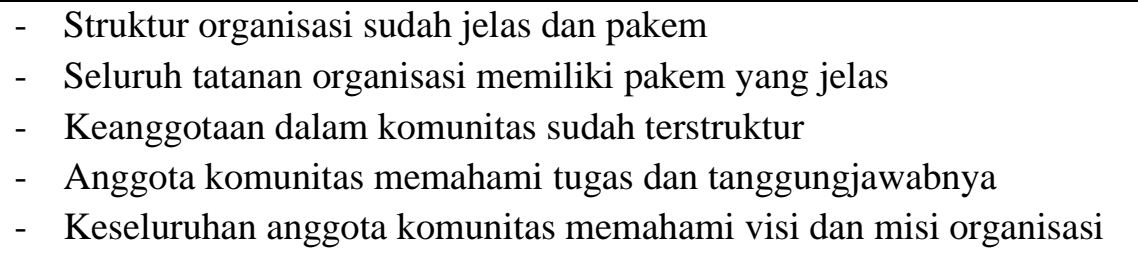 \\
\hline $\begin{array}{l}\text { Program } \\
\text { Kerja }\end{array}$ & $\begin{array}{l}\text { - Penyusunan program kerja yang lebih spesifik dan pakem } \\
\text { - Sistem program kerja dibentuk dengan model program kerja } 3 \text { bulan, } \\
\text { program kerja } 6 \text { bulan, program kerja } 1 \text { tahun } \\
\text { - Menciptakan program kerja yang ikonik pada masing-masing } \\
\text { program kerja tersebut }\end{array}$ \\
\hline SDM & $\begin{array}{l}\text { Mengadakan pelatihan untuk tingkat individu dan komunitas perihal } \\
\text { pelatihan tentang skill maupun tentang ilmu organisasi }\end{array}$ \\
\hline $\begin{array}{l}\text { Mengenal } \\
\text { Dinamika } \\
\text { Sosial } \\
\text { Masyarakat }\end{array}$ & $\begin{array}{l}\text { - } \text { Menggali potensi yang perlu dikembangkan dalam masyarakat desa } \\
\text { Sumbermanjingkulon } \\
\text { - } \text { Bekerjasama dengan aparat desa dengan menganalisis dari tingkat } \\
\text { masing-masing RT dan RW } \\
\text { - } \text { Memahami permasalahan yang sering muncul dalam masyarakat }\end{array}$ \\
\hline $\begin{array}{l}\text { Badan } \\
\text { Hukum }\end{array}$ & $\begin{array}{l}\text { - Memiliki Surat Keputusan (SK) pada Komunitas IPPKT } \\
\text { - } \text { Membuat AD/ART komunitas }\end{array}$ \\
\hline
\end{tabular}

Setelah seluruh anggota mengetahui cara atau faktor apa saja yang dibutuhkan oleh komunitas IPPKT untuk mewujudkan impian bersama, kemudian penulis mengajak seluruh anggota memberikan kontribusi berupa langkah nyata yang akan dilakukan dalam 6 bulan kedepan mewujudkan mimpi bersama terhadap komunitas IPPKT yang sudah dimiliki. Seluruh peserta berdiskusi dan dipandu oleh penulis, berikut adalah detail perencanaan yang dibuat oleh seluruh anggota:

1. Mulai membentuk buku induk komunitas IPPKT dan meminta masing-masing anggota siapa saja yang masih bersedia tetap menjadi anggota pakem komunitas

2. Memulai menyusun penentuan tatanan organisasi seusai dengan minat masingmasing anggota

3. Mengadakan pertemuan setiap satu minggu sekali pada seluruh anggota komunitas untuk berdiskusi secara keseluruhan mengenai langkah-langkah yang akan dilakukan berdasarkan rangkuman strategi yang sudah dibentuk bersama

4. Melakukan pemetaan kebutuhan pelatihan yang akan diadakan komunitas sesuai dengan kebutuhan komunitas maupun individu dan mencari trainer sesuai dengan kebutuhan pelatihan 
5. Berdiskusi bersama untuk meninjau kembali tentang program kerja yang sudah ada sekarang dan disesuaikan dengan program kerja yang dibentuk bersama

6. Mulai membentuk dan membagi tugas pada seluruh anggota komunitas disesuaikan dengan wilayah RT atau RW masing-masing untuk memulai analisis dinamika sosial pada masyarakat desa Sumbermanjingkulon

7. Berdiskusi internal untuk membahas terkait badan hukum dengan membentuk tim khusus yang memiliki kemampuan dalam bidang tersebut

Hal tersebut merupakan wujud komitmen seluruh anggota komunitas untuk mewujudkan perubahan kedepannya. Destiny yang telah diwujudkan bersama akan mendorong kekuatan positif pada komunitas untuk melakukan perubahan dan rancangan rencana perubahan selama 6 bulan kedepan bisa terealisasikan bersama dengan anggota komunitas.

\section{Evalusi dan Refleksi Intervensi}

Pada langkah terakhir ini penulis melakukan evaluasi dan refleksi setelah diadakan intervensi. Pelaksanaan evaluasi dan refleksi ini dilakukan satu bulan setelah intervensi dengan Forum Grup Discussion dan Analisis stastistik Prepostest.

Berikut untuk hasil FGD setelah dilakukannya intervensi.

1. Komunitas mulai mempunyai buku induk organisasi yang akan digunakan sebagai pedoman komunitas.

2. Seluruh anggota mulai menjalankan kembali program kerja yang setiap minggu selalu ada yaitu bersih desa setiap sabtu dan minggu.

3. Pelatihan untuk pengembangan organisasi dan individu sudah direncanakan. Kebutuhan saat ini yang direncanakan yaitu tentang kebutuhan dasar individu yang difokuskan pada masing-masing anggota.

4. Mulai menyusun dan menuliskan program-program kerjanya, dan istilahnya adalah Peta Strategi

5. Komunitas sudah menyusun tim yang akan membentuk badan hukum.

6. Pembentukan tim dinamika sosial dalam masyarakat sudah berjalan dari setelah pelatihan selesai. Beberapa hasil yang sudah terjun kelapangan tersebut salah satunya sudah dijadikan program kerja baru dan masih diproses lebih lanjut.

Proses selanjutnya dengan pengambilan data pretest dan postest yang digunakan untuk melihat apakah benar ada perubahan dari pelaksanaan intervensi, selain itu juga sebagai penguat secara statistik untuk melihat perubahan. Alat ukur dalam pengambilan data tersebut menggunakan Sense Of Community-Index 2 (SCI-Index2) oleh Mc.Millan \& Chavis dengan jumlah 24 item.

Berdasarkan dari hasil signifikansi menggunakan uji Paired-Sampel T-test, akan terdapat dua asumsi yaitu, Ho ditolak bila $\mathrm{p}<0,05$ dan $\mathrm{H} 0$ diterima bila $\mathrm{p}>$ 
0,05. Hal uji juga akan digunakan dalam melakukan uji hipotesis. uji analisis diatas diperoleh nilai signifikansi (2-tailed) sebesar $0,000<0,05$ maka sesuai dengan dasar pengambilan keputusan dalam uji Paired Sample- t-test, dapat disimpulkan Ho ditolak dan Ha diterima yang artinya bahwa appreciative inquiry dapat meningkatkan sense of community dan partisipasi sosial pada anggota komunitas IPPKT. Hal ini juga berdasarkan analisis nilai t hitung $(4,792)>t$ tabel $(1,701)$, karena t hitung lebih besar dari t tabel t tabel dan signifikansi $<0.05$, maka Ho ditolak dan Ha diterima. Oleh karena itu dapat disimpulkan terdapat pengaruh penggunaan appreciative inquiry pada anggota komunitas IPPKT.

\section{Pembahasan}

Appreciative Inquiry yang dilakukan dalam penelitian ini berusaha untuk melibatkan seluruh anggota komunitas mulai dari pendiri komunitas, dewan pertimbangan organisasi serta keseluruhan anggota komunitas supaya mau terlibat dan berkolaborasi menemukan kekuatan dan melakukan perubahan sesuai dengan impian yang dimiliki. Appreciative inquiry berdasarkan hitungan statistic memiliki pengaruh yang signifikan terhadap perubahan komunitas IPPKT.

Pada intervensi tahap I berupa pemberian materi dan penjabaran tentang keadaan komunitas merupakan tahap yang sangat dibutuhkan bagi penulis dan krusial karena dengan adanya pengantar awal sebelum memasuki intervensi Appreciative inquiry akan mempermudah para anggota komunitas untuk memahami lebih mendalam tentang keadaan yang sesungguhnya. Seluruh anggota begitu memahami ketika penulis menjabarkan tentang keadaan saat ini dan dikaitkan dengan teori Adizes lifecycle (2004), pada sesi ini seluruh anggota memberikan umpan balik yang sangat positif dan sangat memahami bahwa komunitas membutuhkan energi yang baru untuk perubahan.

Memasuki intervensi tahap II berupa pelaksanaan Appreciative inquiry yang diawali menggali Discovery dan Dream. Tahapan ini merupakan tahapan yang krusial karena sangat berpengaruh dan membantu sangat membantu penulis untuk melakukan langkah-langkah selanjutnya dalam penelitian ini. Bagi peserta intervensi bahwa pada saat menggali kekuatan dan impian merupakan pengalaman baru selama berorganisasi karena selama ini selalu berfokus pada masalah dan mengesampingkan kekuatan-kekuatan positif.

Pada pelaksanaan sesi Design dan Destiny seluruh peserta menyampaikan ide-ide dan gagasannya dalam wujud langkah nyata yang akan dilakukan untuk mencapai mimpinya yang sudah berada pada pohon impian tersebut. Hasil dari sesi Design yang sudah dijelaskan pada penjabaran diatas. Dengan adanya langkah nyata tersebut menjadi sebuah visi yang dapat menggerakkan seluruh anggota untuk melakukan perubahan dalam komunitas IPPKT.

Sasaran perubahan yang dituju dalam proses pengembangan organisasi pada 
penelitian ini adalah meningkatkan sense of community dan partisipasi sosial komunitas IPPKT yang terindikasi dari perubahan seluruh anggota untuk lebih memiliki rasa kebersamaan dalam komunitas dan mau terlibat secara aktif dalam mengemban tugas dan tanggungjawab untuk mencapai tujuan organisasi. Hal tersebut dapat tercapai dengan menggunakan appreciative inquiry yang terlihat dari teridentifikasinya hal-hal yang dibutuhkan untuk terjadi perubahan dan langkah nyata yang akan dilakukan selama 1 hingga 6 bulan kedepan serta dapat terlihat pula dari hasil perhitungan statistika tersebut bahwa nilai signifikansinya $0,000<0,05$ yang berarti Appreciative inquiry memiliki pengaruh yang signifikan dalam melakukan perubahan.

Dari pelaksanaan intervensi tersebut terlihat bahwa Appreciative inquiry berhasil meningkatkan sense of community dan partisipasi sosial anggota komunitas IPPKT, diantaranya dalam aspek Sense of community salah satunya membership yang mana akan menciptakan keanggotaan yang saling berinteraksi dan menciptakan rasa memiliki bersama anggota lainnya. Sehingga akan menciptakan anggota yang memiliki keterlibatan secara aktif dalam komunitas. Setelah intervensi selesai dilaksanakan, penulis melakukan evaluasi dengan metode FGD bersama para kelompok pengarah dan Dewan Pertimbangan Organisasi yang bertujuan untuk berdiskusi apakah setelah dilakukan intervensi ada perubahan atau masih belum dilakukan perubahan.

Berdasarkan perhitungan statistik yang telah dilakukan, hasil perhitungan tersebut menunjukkan bahwa adanya peningkatan pada sense of community dan partisipasi sosial disimpulkan dari hasil pengukuran skala sense of community. Selain itu berdasarkan uji T-test hasil yang diperoleh menunjukkan signifikansi < 0,05 yang berarti terdapat pengaruh pemberian intervensi appreciative inquiry untuk meningkatkan sense of community dan partisipasi sosial. Sesuai dengan dalam penelitian Falatehan (2017) bahwa semakin meningkatnya sense of community maka semakin tinggi pula tingkat partisipasi sosial anggota.

Sense of community penting untuk suatu organisasi sosial karena dapat membuat anggota komunitas memiliki tanggungjawab serta keaktifan dalam menjalankan tugas sebagai anggota komunitas dilingkungannya. Salah satu indikator adanya partisipasi adalah sense of community. Menurut Falatehan (2014) individu yang memiliki sense of community cenderung lebih mudah untuk berpartisipasi sosial dalam program yang dijalankan dalam komunitas karena memiliki ikatan sejarah dan pengalaman yang sama.

Partisipasi sosial berhubungan signifikan dengan sense of community, hal tersebut seperti penelitian yang dilakukan oleh Fadillah (2017). Jika Sense of community dalam kegiatan di komunitas meningkat maka akan meningkat pula partisipasi anggota, sehingga membuat keberlanjutan program kerja komunitas tetap terjaga dan mampu untuk mencapai tujuan organisasi (McMillan, 2011). 
Pada penelitian pembangunan kapasitas masyarakat di dunia turisme, kurangnya sense of community merupakan salah satu alasan penyebab masyarakat tidak berpartisipasi (DeNeui, 2003). Sense of community memiliki kemampuan untuk mempengaruhi anggota termasuk juga terhadap partisipasi anggota lainnya. McMillan (1986) mendefinisikan hal tersebut sebagai ketergantungan antara individu dengan komunitasnya, yang berarti bahwa jika sense of community rendah maka berakibat pada kurangnya keterlibatan aktif pada anggota komunitas dalam menjalankan program kerja.

Wujud dari partisipasi sosial meningkat dalam anggota komunitas ini dapat dilihat bahwa setiap anggota sudah proaktif dan siap bertanggungjawab dengan program kerja yang telah disusun bersama. Anggota mulai melangkah menyusun strategi dan sudah menentukan langkah lanjut dalam program kerja yang sudah disusun bersama. Anggota komunitas sudah memiliki peran penting dalam mewujudkan keberlanjutan komunitas. Hal tersebut sesuai dengan hasil FGD bersama para pemangku jabatan dalam komunitas bahwa, antusias dari para anggota komunitas sangat tinggi, mereka mulai berpartisipasi aktif untuk ikut andil dalam setiap pengambilan keputusan dan tampak dari kegiatan program mingguan mereka mulai aktif kembali menggalakkan kebutuhan dalam komunitas.

\section{KESIMPULAN}

Berdasarkan proses dan hasil penelitian yang bertujuan untuk melakukan perubahan dalam rangka meningkatkan sense of community dan partisipasi sosial anggota komunitas IPPKT sehingga bisa terlibat secara aktif untuk mencapai tujuan organisasi. Diperoleh kesimpulan bahwa intervensi Appreciative Inquiry yang digunakan cukup berhasil membuat anggota komunitas tergerak untuk melakukan perubahan dan mengidentifikasi hal-hal yang dibutuhkan dalam perubahan sehingga dapat merencanakan langkah nyata. Selain itu intervensi Appreciative inquiry mampu untuk membuat seluruh anggota komunitas IPPKT berpartisipasi aktif menumbuhkan perasaan bangga, senang, dan termotivasi untuk melakukan perubahan dalam mencapai keadaan yang diimpikan.

\section{SARAN}

Untuk dapat mempertahankan perubahan yang telah terwujud pada masingmasing anggota komunitas IPPKT, maka perlu menentukan program yang nantinya akan berpengaruh dan bermanfaat pada individu tersebut serta akan bersifat jangka panjang dalam mengembangkan keberlanjutan komunitas IPPKT. Dalam hal ini yang telah dilakukan yaitu dengan memberikan pelatihan yang telah disusun untuk individu dan kebutuhan organisasi, sehinga masing-masing individu memiliki hasil dan ilmu baru untuk bisa tetap bertahan dalam komunitas serta mengembangkan komunitas. Selain itu untuk tetap menjaga keberlangsungan 
anggota dalam komunitas dengan memberikan kesempatan kepada masing-masing anggota untuk menyampaikan ide dan kreativitasnya, kemudian dari anggota yang memberikan ide ditunjuk sebagai koordinator pelaksana. Dengan melakukan hal tersebut bisa mendorong anggota semakin berantusias dan berpartisipasi secara aktif karena merasa bahwa setiap ide dan pendapatnya dihargai. Hal tersebutlah salah satu untuk bisa menjaga konsistensi anggota untuk tetap terlibat secara aktif dalam komunitas IPPKT.

\section{DAFTAR PUSTAKA}

Adizes, I. (2004). Managing corporate lifecycles. The adizes institute publishing.

Aref, Faribozz., Redzuan, Ma'rof., dan Gill, S Sarjit. (2010). Community Capacity Building: A Reiew of its Implication in Tourism Development. Journal of American Science. Vol $6 \quad$ (1). http://www.jofamericanscience.org/journals/am$\underline{\text { sci/am0601/23_1102_Dimensions_am0601.pdf }}$

Bukov, Mass \& Lampert (2002). Social Participation in Very Old Age: CrossSectional and Longitudinal Findings From BASE.Journal of Gerontology: Pychological Science.Vol. 57B, (6). doi:10.1093/geronb/57.6.p510

Brakel, V. Wim. (2010). Participation Scale Users Manual Version 6.0. KIT Leprosy Unit. Press Wibautstraat 137J: 5-7

Chavis DM, Lee K, Acosta JD. (1996). The Sense of Community (SCI) Index revised: the reliability and the validity of the SCI-2. Paper presented at the 2nd International Community Psychology Conference.

Chavis, David M. and Wandersman, Abraham. (1990). Sense of community in the Urban Environment: A Catalyst for Participation in Community Development. American Journal of Community Psychology (18:1),pp. 5581. https://doi.org/10.1007/BF00922689

Cifalino, Antonella dan Baraldi, Stefano. (2009). Training Programs and performance measurement: Evidence from healthcare organisations. Journal of Human Ressource Costing \& Accounting, Vol 13 No.04, pp. 294-315.doi: 10.1111/ijtd.12055

Coghlan, David dan Brannick, Teresa. (2005). Doing Action Research In Your Own Organization 2th Edition. London: Sage Publications.

Cooperider DL, Whitney D, Stavros JM. (2008). Appreciative Inquiry Handbookfor leaders of Change 2th Edition. Crown Custom Publishing. Inc: Ohio. 
Dhiana, Anggraeni. 2008. Meningkatkan Partisipasi Masyarakt dalam kegiatan Pengurangan Resiko Banjir di RW 03 Keluruhan Cawang Jakarta Timur dengan teknik Appreciative Inquiry. Tesis pada Psikologi UI: tidak diterbitkan

Evans, S. D. (2007). Youth Sense of Community: Voice and Power Incommunity contexts. Journal Of Community Psychology, 35 (6), 693-709. https://doi.org/10.1002/jcop.20173

Fadillah, H. Krisna. 2017.Hubungan Sense Of Community dengan Partisipasi Sosial Anggota Komunitas Gerakan Perpustakaan Aanak Nusantara (GPAN) Malang. Skripsi. Fakultas Psikologi. Universitas Muhammdiyah Malang. Malang. http://eprints.umm.ac.id/43799/

Falatehan, F Sriwulan. (2017). Pendekatan Psikologi Komunitas Dalam Memprediksi Peranan Rasa Memiliki Komunitas Terhadap Munculnya Partisipasi Masyarakat. Jurnal Ilmiah Psikologi. Vol. 6 (1). Pp. 66-90. http://ejournal.atmajaya.ac.id/index.php/Manasa/article/view/174/352

Grace, D. (2006). Psychological Sense of community and its relevance to wall being and everyday life in Australia. The Australian Psychological Society. Ltd, Level 11, 257. (25) 6-7

Kalimang, E.S Sufia. (2016). Pengaruh Penggunaan Aprreciative Inquiry untk Meningkatkan Rasa Bermasyarakat (Sense Of Community) Kader Lingkungan Pada Program Lamongann Green and Clean di Kab. Lamongan. Tesis. Fakultas Psikologi. Universitas Airlangga. Surabaya

Kotter, John P. \& Cohen, Dan S. (2002). The Heart of Change: Real-Life Storiesof How People Change Their Organizations. Boston: Harvard Business Review Press

Levasseur, M. (2008). Do quality of life, participation and environment of older adults differ according to level of activity?".Health Qual Life Outcomes.6: 30.doi: $\underline{10.1186 / 1477-7525-6-30}$

Loren O. Osbarn dan Martin H. Neumeyer.(1984).Community and Society" Suncy. Inc

McMillan, D. W. (2011). Sense of community, a theory not a value: a response to Nowell and Boyd. Journal of Community Psychology, 39(5), 507519. doi:10.1002/jcop.20439

McMillan DW, Chavis DM. (1986). Sense of community: a definition and theory. JournalCommunityPsychology.4:6-23. https://pdfs.semanticscholar.org/e5fb/8ece108aec36714ee413876e61b0510 


\section{e7c80.pdf}

McNiff, Jean dan Whitehead, Jack. (2006). All You Need To Know About Action Research. London: Sage Publications.

Nelson, G., \& Prilleltensky, I. (2005). Coomunity Psychology In Pursuit of Liberation and Wll-Being. New York: Palgrave MacMillan.

Ohmer, Mary. (2007). Citizen Participation in Neighborhood Organizations and Its Relationship to Volunteers' Self- and Collective Efficacy and Sense of Community. Journal of Social Worker Research. Vol 31 (2). https://doi.org/10.1093/swr/31.2.109

Peterson, N. A., Speer, P. W., \& McMillan, D. W. (2007). Validation of A brief sense of community scale: Confirmation of the principal theory of sense of community. Journal of Community Psychology, 36(1), 6173. doi: $10.1002 /$ jcop. 20217

Piskur, Barbara dkk. (2013). Participation and social participation: are they distinct concepts?. Journal Clinical Rehabilitation. 28 (3). doi: $\underline{10.1177 / 0269215513499029}$

Rothwell, William J dan Sullivan, Roland L. (2005). Practicing Organization Development: A Guide for Consultants (2nd Edition). San Fransisco: Pfeiffer.

Sugiyono. (2008). Metode Penelitian Kualitatif, Kuantitatif dan R\&D. Bandung: Alfabeta.

Whitney, D., \& Bloom, A. T. (2003). The power of appreciative inquiry: A practical guide to positive change. San Fransisco: BK Publisher, Inc.

Wiseman, R.L,. Gonzales, S.M \& Salyer, K. (2004). A cross cultural analysis of student sense of community degree of involvement an educational benefits. Jurnal Intercultural Communication Studies, 8 (1).

Zuriel, J.G.T. (2012). Using AI Community Development Planning And Transformation Framework From Roots To Wings The Collage of Maasin. 